Tropical Journal of Pharmaceutical Research April 2015; 14 (4): 693-700

ISSN: $1596-5996$ (print); 1596-9827 (electronic)

(C) Pharmacotherapy Group, Faculty of Pharmacy, University of Benin, Benin City, 300001 Nigeria.

All rights reserved.

Available online at http://www.tjpr.org

Original Research Article

http://dx.doi.org/10.4314/tjpr.v14i4.19

\title{
Effect of Smoking on Pharmacokinetics of Clopidogrel, an Antiplatelet Drug
}

\author{
Ola Diab ${ }^{1}$, Tawfiq Arafat ${ }^{2,3}$ and Al-Motassem Yousef ${ }^{1 *}$ \\ ${ }^{1}$ Department of Biopharmaceutics and Clinical Pharmacy, Faculty of Pharmacy, The University of Jordan, ${ }^{2}$ Jordan Center for \\ Pharmaceutical Research, ${ }^{3}$ Pharmaceutical Medicinal Chemistry \& Pharmacognosy, Petra University, Amman, Jordan
}

*For correspondence: Email: ayousef@ju.edu.jo; Tel: 962-777486930; Fax: 962-6-5339649

Received: 16 May 2014

Revised accepted: 20 February 2015

\begin{abstract}
Purpose: To assess the influence of smoking cigarettes on the pharmacokinetics of the antiplatelet drug, clopidogrel.

Methods: Thirty four male patients, mean age and weight of 59.3 years and $81.1 \mathrm{~kg}$, respectively, who underwent percutaneous coronary intervention (PCl), took part in the study. Each subject received an oral loading dose of $600 \mathrm{mg}$ clopidogrel eight tablets, each $75 \mathrm{mg}$ ). Clopidogrel carboxylate plasma level was measured and non-compartmental analysis was used to determine peak plasma concentration $\left(C_{\max }\right)$, time to achieve peak plasma concentration $\left(T_{\max }\right)$, elimination half-life $\left(t_{1 / 2 e}\right)$, and area under the curve $\left(A \cup C_{0-\infty}\right)$. Other parameters measured include gamma-glutamyltransferase enzyme (GGT), low density lipoprotein cholesterol (LDL-cholesterol), blood urea nitrogen (BUN) and platelet count.

Results: Nineteen patients were smokers (55.9\%). Smokers had higher levels of GGT compared to non-smokers (31.73 \pm 14.42 vs. $21.63 \pm 11.41 \mathrm{IU} / \mathrm{L}, p=0.08)$ as well as higher levels of $L D L$-cholesterol (116.79 \pm 42.08 vs. $87.07 \pm 27.34 \mathrm{mg} / \mathrm{dl}, p=0.041$, respectively). Smokers had shorter half-life (smokers: $3.47 \pm 1.9 \mathrm{~h}$ vs. non-smokers: $5.83 \pm 4.09 \mathrm{~h}, p=0.012$ ). Smoking behavior had no influence on $C_{\max }(p=0.16)$, $A \cup C_{0-\infty}(p=0.65)$ or $T_{\max }(p=0.91)$. In general, the pharmacokinetic parameters were characterized by considerable inter-individual variation $\left(C_{\max }=23.2 \pm 8.79 \mu \mathrm{g} / \mathrm{ml}\right.$, coefficient of variation $(\mathrm{CV})=37.9 \%),\left(T_{\max }=1.71 \pm 1.15 \mathrm{~h}, \mathrm{CV}=67.2 \%\right),\left(A \cup C_{0-\infty}=120.97 \pm 44.4 \mu \mathrm{g} . \mathrm{h} / \mathrm{ml}, \mathrm{CV}=\right.$ $36.7 \%)$ and $\left(t_{1 / 2 e}=4.57 \pm 3.15 h, C V=68.9 \%\right)$.

Conclusion: Smoking behavior may not be a significant determinant of the pharmacokinetics of clopidogrel following oral administration of $600 \mathrm{mg}$ dose in patients undergoing PCl.
\end{abstract}

Keywords: Antiplatelet, Clopidogrel, Pharmacokinetics, Smoking, Cigarette

Tropical Journal of Pharmaceutical Research is indexed by Science Citation Index (SciSearch), Scopus, International Pharmaceutical Abstract, Chemical Abstracts, Embase, Index Copernicus, EBSCO, African Index Medicus, JournalSeek, Journal Citation Reports/Science Edition, Directory of Open Access Journals (DOAJ), African Journal Online, Bioline International, Open-J-Gate and Pharmacy Abstracts

\section{INTRODUCTION}

Clopidogrel is an antiplatelet agent which selectively inhibits the binding of adenosine diphosphate (ADP) to its platelet receptor (P2Y12) and blocks the subsequent platelet aggregation [1]. Clopidogrel is particularly important in prevention of coronary thrombosis and highly valuable in patients undergoing coronary revascularization [2,3]. Recently published studies revealed a marked interindividual variability to clopidogrel inhibition of ADP-induced platelet aggregation [4]. It is estimated that laboratory clopidogrel nonresponsiveness can be found in $20 \%$ of patients undergoing percutaneous coronary intervention $(\mathrm{PCl})$. This is alarming as the consequences of stent thrombosis are grave with high rates of 
death, myocardial infarction (MI), and repeat vascularization [5].

The causal link between smoking and premature coronary arterial disease (CAD) is well demonstrated [6]. Smoking cessation is the single most important intervention for primary and secondary prevention of CAD [7]. Furthermore, a recent large meta-analysis of prospective double blind randomized controlled trials of paclitaxel-eluting stents found that early stent thrombosis (< 30 days) was strongly and independently associated with smoking with an overall mortality rate of $41.2 \%$ [5].

A phenomenon termed "Smoking Paradox" had been noticed with smokers on clopidogrel therapy, in which smoking enhances clopidogrel pharmacodynamics, and smoker patients on clopidogrel had lower platelets reactivity [8]. Additionally it showed a lower incidence of allcause mortality and that treatment is more effective at reducing the rate of cardiovascular death, myocardial infarction, or urgent revascularization through 30 days among those who smoked $\geq 10$ cigarettes/day compared with those who did not [8-10]. Other evidence shows that current smokers ( $\geq 10$ cigarettes/day) had low platelet reactivity [11] and lower active GP IIb/IIla expression [12] compared with nonsmokers. This finding contradicts the very well established notion that smoking is an independent risk factor for coronary vascular disease (CVD) [13].

Our objective is to assess the effect of tobacco smoking, on the pharmacokinetics of clopidogrel among patients receiving $600 \mathrm{mg}$ clopidogrel and undergoing $\mathrm{PCl}$.

\section{EXPERIMENTAL}

\section{Study population}

Patients (men) who were admitted to Jordan University Hospital for catheterization and underwent $\mathrm{PCl}$ would be eligible for the entry into this study if they were given $600 \mathrm{mg}$ of Plavix $®$ (clopidogrel), and consented to participate. Patients were excluded if they were known to have hepatitis $B$ infection or carrier of respective antigen; donated blood within last 2 months; have allergic diathesis or any significant allergic disease; have GI diseases or hepatic disease; were pregnant; have creatinine clearance < $60 \mathrm{ml} / \mathrm{min}$; or diagnosed with heart failure with NYHA class 4.
The study was approved by local Research Ethics Committees of the Jordan University Hospital (approval reference number $\mathrm{M} / \mathrm{C} / \mathrm{A} / 111 / 1519)$ and informed consent was obtained from all participants after having been informed verbally by the medical supervisor about the need to withdraw extra blood samples for pharmacokinetic analysis. The decision to give or not to give $600 \mathrm{mg}$ clopidogrel was solely the responsibility of the treating cardio-surgeon performing the $\mathrm{PCl}$. Various laboratory tests were conducted prior to the procedure for each patient. These include serum creatinine, blood urea nitrogen and sodium; liver function (total proteins, albumin, aminotransferases, and alkaline phosphatase); lipid profile and complete blood count.

To be included in the study, smokers were defined as those who smoked least 3 cigarettes per day for at least one year. Non-smokers were defined as patients who never smoked cigarettes or water pipe. Patients who used to smoke and quitted (i.e., ex-smokers) were not included in the study irrespective of the period of smoking cessation.

\section{Sample size calculation}

The sample size needed to evaluate the influence of smoking on $\mathrm{C}_{\max }$ of clopidogrel carboxylic acid metabolite was calculated using equation 1:

$N=2 x(S D / \Delta)^{2} x\left(Z_{1-\alpha / 2}+Z_{1-\beta}\right)+0.25\left(Z_{1-\alpha / 2}\right) \ldots \ldots \ldots$

where SD is the estimated standard deviation; $\Delta$ is the practical significant difference of the mean (33 \% of mean); $Z_{1-\alpha / 2}$ is the level of significance ( $\alpha$ level $=0.05$ ); and $Z_{1-\beta}$ is the power of the study $(\beta$ level $=0.2)$. We assumed $A C_{0-\infty}$ (198.6 \pm $52.4 \mu \mathrm{g} . \mathrm{h} / \mathrm{ml}$ ) based on previously published data [14]. The minimum sample size to detect a difference of at least $60 \mu \mathrm{g} . \mathrm{hr} / \mathrm{ml}$ in $\mathrm{AUC}_{0-\infty}$ was calculated to be 12 . The sample size was further increased to 15 to account for potential data points below lower limit of detection $(0.5 \mu \mathrm{g} / \mathrm{ml})$ over the observation period (8 h).

\section{Intervention and sample collection, chroma- tographic conditions and pharmacokinetic calculations}

The blood sampling, condition of HPLC and pharmacokinetics parameters were reported in previous work [15]. In summary, a whole blood samples from patients were drawn into heparinized test tubes at different time points. Plasma samples were separated and immediately stored at $-80{ }^{\circ} \mathrm{C}$ until analysis. The 
plasma level of clopidogrel carboxylic acid were determined by reverse-phase high-performance liquid chromatographic method, where the separation achieved using isocratic mobile phase. A Dionex $\circledR$ HPLC autosampler system was used All separations were performed at room temperature. Detection was monitored at $220 \mathrm{~nm}$.

The pharmacokinetic parameters of clopidogrel carboxylic acid metabolite were estimated by standard non-compartmental methods using KineticaTM 2000 Version 4.2 (Innaphase, Philadelphia, PA, USA).

\section{Laboratory parameter measurements}

LDL, BUN, GGT and other parameters were measured by standardized and validated methods adopted by Jordan University labs.

\section{Data analysis}

Statistical analysis was performed using SPSSC software (version 16.0; SPSS, Inc, Chicago, IL). Data were expressed as mean $\pm S D$. Coefficient of variation (CV) was calculated by as (mean/SD)*100. Normal probability distribution of pharmacokinetic parameters was determined visually by the probability plot (P-P) and quantilequantile (Q-Q) plot and examining the Kolmogorov-Smirnov-Lilliefors test (K-S test). Equality of variance was assessed by levene's test. The effect of smoking on pharmacokinetic parameters $\left(\mathrm{C}_{\max }, \mathrm{T}_{\max }\right.$ and $\left.\mathrm{AUC}_{0-\infty}\right)$ was assessed by independent Student t-test. However, Mann-Whitney was utilized to test the effect of smoking on $t_{1 / 2 \mathrm{e}}$. Linear association between pharmacokinetic parameter, $t_{1 / 2 e}$, and laboratory data (LDL, platelet, BUN and GGT) was tested with Pearson's correlation coefficient.

\section{RESULTS}

\section{Patients' characteristics}

Thirty four male patients received $600 \mathrm{mg}$ clopidogrel loading dose in the study. Patients had an average age of $59.3 \pm 9.0$ years (range: $44-82$ years), mean height of $173.7 \pm 7.0 \mathrm{~cm}$ (range: $155-187 \mathrm{~cm}$ ), average weight of $81.4 \pm$ $12.6 \mathrm{~kg}$ (range: $65-116 \mathrm{~kg}$ ), and mean BMI of $26.96 \pm 4.25 \mathrm{kgm}^{-2}$ (range: $21.7-38.0 \mathrm{kgm}^{-2}$ ) (Table 1).

With regard to laboratory results, patients had normal kidney function (serum creatinine, blood urea nitrogen and sodium); liver function (total proteins, albumin, aminotransferases, and alkaline phosphatase); lipid profile and complete blood count (Table 2).

More than one half of participants were smokers ( $n=19$ ). All smokers except two smokers smoked more than 10 cigarettes per day with a mean of 35.6 (range: 3 - 80) cigarettes per day. Smokers and non-smokers had similar medical conditions, prior to admission medications, demographic characteristics, laboratory and physical examination except for one parameter LDL-Cholesterol. Smokers had higher levels of LDL-cholesterol $(116.79 \pm 42.08$ vs. $87.07 \pm$ $27.34 \mathrm{mg} / \mathrm{dl}, p=0.041)$.

Table 1: Demographic and clinical characteristics of recruited patients

\begin{tabular}{|c|c|c|}
\hline Parameter & Smokers (N = 19) & Non-smokers $(\mathrm{N}=15)$ \\
\hline Age (years, $\pm S D$ ) & $56.7 \pm 10.2$ & $62.6 \pm 5.8$ \\
\hline Body mass index $\left(\mathrm{kg} / \mathrm{m}^{2}, \pm S D\right)$ & $29.3 \pm 3.5$ & $27.9 \pm 5.08$ \\
\hline \multicolumn{3}{|l|}{ Concomitant disease (N) } \\
\hline Hypertension & 12 & 12 \\
\hline Diabetes mellitus & 8 & 9 \\
\hline Dyslipidemia & 5 & 4 \\
\hline Coronary artery disease & 8 & 11 \\
\hline \multicolumn{3}{|l|}{ Pre-admission medication history } \\
\hline Aspirin & 13 & 14 \\
\hline Beta adrenergic receptors blockers & 8 & 12 \\
\hline ACEIs / ARBs & 9 & 8 \\
\hline HMGCo-reductase inhibitors & 11 & 12 \\
\hline Proton pump inhibitors & 5 & 3 \\
\hline
\end{tabular}


Table 2: Biochemical, heamatological and renal profile of patients included in the study

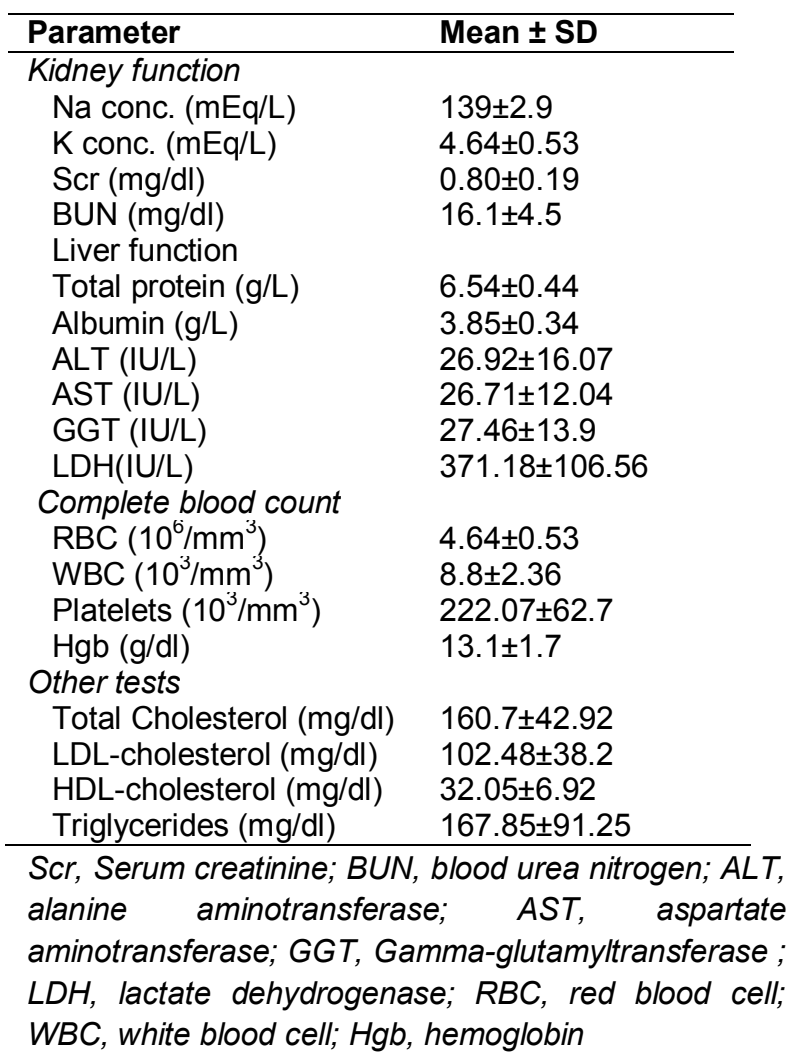

Another two laboratory parameters were also different between two groups of study, where smokers had higher GGT levels (31.73 \pm 14.42 vs.21.63 $\pm 11.41, p=0.08$ ) but lower level of blood urea nitrogen $(12.94 \pm 2.6$ vs. $15 \pm 3.06$ $\mathrm{mg} / \mathrm{dl}, p=0.073$ ) (Table 3).

None of these differences is expected to be clinically relevant as they were all within normal range. Additionally, none of these differences is expected to influence the pharmacokinetic parameter values.

\section{Pharmacokinetic parameters}

The primary pharmacokinetic parameters of clopidogrel carboxylic acid metabolites are reported in table 4 . Independent of smoking status, the plasma levels were characterized with significant variability $\left(\mathrm{C}_{\max }=23.21 \pm 8.79 \mu \mathrm{g} / \mathrm{ml}\right.$, $\mathrm{CV}=37.9 \%),\left(\mathrm{T}_{\max }=1.71 \pm 1.15 \mathrm{~h}, \mathrm{CV}=67.2\right.$ $\%),\left(\mathrm{AUC}_{0-\infty}=120.97 \pm 44.4 \mu \mathrm{g} . \mathrm{h} / \mathrm{ml}, \mathrm{CV}=36.7\right.$ $\%)$, and $\left(\mathrm{t}_{1 / 2 \mathrm{e}}=4.57 \pm 3.15 \mathrm{~h}, \mathrm{CV}=68.9 \%\right)$.

Regarding the two groups of study, smokers had shorter half-life $(p=0.012)$. However, smoking behavior had no statistically significantly influence on $\mathrm{C}_{\max }, \mathrm{AUC}_{0-\infty}$ nor on $\mathrm{T}_{\max }$ (Table 4).

Since differences between smokers and nonsmokers were found for variables such LDL, GGT and BUN, it was necessary to analyze the possible contribution of these co-variables to the explanation of the significant differences found for $t_{1 / 2 \mathrm{e}}$.

Accordingly, a correlation study was done for $t_{1 / 2 e}$ against these variables (Table 5).

There was no statistically significant correlation between $t_{1 / 2 e}$ and LDL-Cholesterol, GGT or BUN (Table 5). The only significant correlation was with smoking status that decreases $t_{1 / 2 \mathrm{e}}$ by 2.36 hr on average.

\section{DISCUSSION}

Clopidogrel is an important antiplatelet agent that has application in the primary and secondary prevention of cardiovascular complications especially among patients unable to take aspirin. In patients who undergo $\mathrm{PCl}$, dual antiplatelets consisting of aspirin and clopidogrel is the regimen of choice to prevent thrombotic complications $[2,16]$. Following oral administration, clopidogrel is rapidly absorbed and undergoes extensive hepatic metabolism [17]. The parent drug is inactive and hepatic biotransformation is necessary for its antiplatelet activity [18]. The inactive carboxylic acid metabolite is the most abundant species found in plasma at high concentrations [17].

Table 3: Differences in laboratory data findings between smokers and non-smokers

\begin{tabular}{lccc}
\hline Parameter & \multicolumn{3}{c}{ Mean \pm SD } \\
\cline { 2 - 4 } & $\begin{array}{c}\text { Non-smokers } \\
(\mathbf{n}=\mathbf{1 5})\end{array}$ & $\begin{array}{c}\text { Smokers } \\
(\mathbf{n}=\mathbf{1 9})\end{array}$ & $\boldsymbol{P}$-value \\
\hline $\mathrm{LDL}^{+}$ & $87.07 \pm 27.34$ & $116.79 \pm 42.08$ & $0.041^{\mp}$ \\
$\mathrm{GGT}^{+}$ & $21.63 \pm 11.41$ & $31.73 \pm 14.42$ & $0.08^{\S}$ \\
$\mathrm{BUN}^{\dagger}$ & $15.0 \pm 3.06$ & $12.94 \pm 2.60$ & $0.073^{\ddagger}$
\end{tabular}

${ }^{+}$Data were missing for four patients; ${ }^{\ddagger}$ Differences were assessed using independent $t$-test; ${ }^{\S}$ Differences were assessed using Mann-Whitney test; LDL-Cholesterol, low density lipoprotein; GGT, Gamma-glutamyl transferase; BUN, blood urea nitrogen 
Table 4: Pharmacokinetic parameters of Clopidogrel carboxylic acid in patients after taking 600 mg clopidogrel

\begin{tabular}{|c|c|c|c|c|}
\hline \multirow[b]{2}{*}{ Parameter } & \multicolumn{4}{|c|}{ Mean $\pm S D$} \\
\hline & $\begin{array}{c}\text { All } \\
(n=34)\end{array}$ & $\begin{array}{c}\text { Non-smokers } \\
(n=15)\end{array}$ & $\begin{array}{c}\text { Smokers } \\
(n=19)\end{array}$ & $P$-value \\
\hline \multicolumn{5}{|l|}{$C_{\max }(\mu \mathrm{g} / \mathrm{ml})$} \\
\hline Mean $\pm S D$ & $23.21 \pm 8.79$ & $20.38 \pm 6.48$ & $25.44 \pm 9.85$ & \\
\hline Min-Max & $7.7-46$ & $8.9-30.13$ & $7.7-46$ & 0.16 \\
\hline Median & & 22.30 & & \\
\hline \multirow[t]{2}{*}{ CV\% } & 23.92 & $31.79 \%$ & 24.96 & \\
\hline & $37.87 \%$ & & $38.71 \%$ & \\
\hline \multicolumn{5}{|l|}{$T_{\max }(h)$} \\
\hline Mean $\pm S D$ & $1.71 \pm 1.15$ & $1.91 \pm 1.50$ & $1.57 \pm 0.8$ & \\
\hline Min-Max & $0.75-6$ & $0.75-6$ & $0.75-4.06$ & 0.91 \\
\hline Median & 1.075 & 1.03 & 1.13 & \\
\hline CV\% & $67.25 \%$ & $78.53 \%$ & $50.96 \%$ & \\
\hline \multicolumn{5}{|c|}{$\mathrm{AUC}_{0-\infty}(\mu \mathrm{g} \cdot \mathrm{hr} / \mathrm{l})$} \\
\hline Mean $\pm S D$ & $120.97 \pm 44.4$ & $129.7 \pm 56.19$ & $115 \pm 34.7$ & \\
\hline Min-Max & 64-282.2 & $67.02-282.2$ & 64-191 & 0.65 \\
\hline Median & 113.17 & 118.60 & 113.13 & \\
\hline CV\% & $36.70 \%$ & $43.32 \%$ & $30.17 \%$ & \\
\hline \multicolumn{5}{|l|}{$t_{1 / 2 e}(h)$} \\
\hline Mean $\pm S D$ & $4.57 \pm 3.15$ & $5.83 \pm 4.09$ & $3.47 \pm 1.9$ & \\
\hline Min-Max & $0.52-10.48$ & $2.87-10.48$ & $0.52-9.02$ & 0.012 \\
\hline Median & 3.89 & 4.47 & 3.17 & \\
\hline CV\% & $68.92 \%$ & $70.15 \%$ & $54.75 \%$ & \\
\hline
\end{tabular}

Table 5: Pearson correlation coefficient between elimination half-life and patients' biochemical data

\begin{tabular}{|c|c|c|}
\hline Parameter & Pearson correlation & $p$ value \\
\hline BUN & 0.293 & 0.123 \\
\hline LDL-cholesterol & -0.17 & 0.424 \\
\hline GGT & -0.083 & 0.703 \\
\hline
\end{tabular}

BUN, blood urea nitrogen; LDL-Cholesterol, low density lipoprotein; GGT, Gamma-glutamyl transferase

Pharmacokinetic studies of clopidogrel have been performed by measuring plasma levels of either the parent drug [19] or the carboxylic acid metabolite as an indirect approach $[17,20]$. It has been proposed that information on the absorption and elimination of clopidogrel after oral administration can be derived from the pharmacokinetics of carboxylate metabolite [17].

This research does not address the interaction of smoking behavior with pharmacodynamics of clopidogrel as there are numerous papers published with this regards $[11,12,21]$. On the other hand only one publication was found on the interaction at the pharmacokinetics level of $75 \mathrm{mg}$ clopidogrel in patients [8].

The current study aimed to evaluate the effect of smoking on pharmacokinetic parameters of clopidogrel loading dose of $600 \mathrm{mg}$ in CAD patients planned for $\mathrm{PCl}$. Influence of smoking is important to study as smoking has been associated with platelet hyperactivity, increased cardiovascular risk [6] and it has been found recently to alter the pharmacokinetics parameters of $75 \mathrm{mg}$ clopidogrel in healthy volunteers [22], as well as in patients [8].
The current study revealed that smoking affected at least one pharmacokinetics parameters of clopidogrel carboxylate in smokers. Smokers had lower $\mathrm{AUC}_{0-\infty}$ by $11.5 \%(p=0.65)$ and had shorter half life by $40.5 \%(p=0.012)$. It has been proposed that smoking may change drugs' pharmacokinetics through higher gastric secretion [23] and decreased gastric blood flow [24]. It is unlikely that the effects of smoking on stomach acidity and gastric blood supply contributed to the observed difference on half life as $\mathrm{C}_{\max }$ and $\mathrm{AUC}_{0-\infty}$ were not different between smokers and non-smokers. On the other hand, smoking has been found to interfere with a variety of CYP isoforms; to induce CYP1A2 $[25,26]$, to interact with CYP2C19 [27], and to increase the expression of CYP3A5 [28,29]. Alternatively, smoking was proposed to increase renal clearance [30] by induction of a renal transport protein[30], thus may decrease the elimination half-life as it has been noticed in the current study and in a previous work [22].

The finding of current study parallel our previous work that linked smoking behavior with clopidogrel pharmacokinetics in healthy male volunteer [22], where smokers had shorter halflife of carboxylic acid metabolite after 
administration of a $75 \mathrm{mg}$ single dose clopidogrel by $35 \%$. Smokers also had lower Cmax and AUC compared to non-smokers [22], this also was noticed by the PARADOX study, in which smokers on Clopidogrel therapy had lower Cmax and AUC compared to non-smokers, and had higher exposure to clopidogrel active metabolite compared to non-smokers that can be explained by higher activation of CYP1A2 enzyme as mentioned earlier [8].

It was established that smoking is one of the major risk factors for cardiovascular diseases, dyslipidemia, diabetes, cancers, respiratory diseases and other diseases [31]. Paradoxically it has been found recently that smoking potentiates the effect of clopidogrel $[8,10,11]$, where current smokers on clopidogrel therapy showed lower platelet activity and greater platelet inhibition compared to non-smokers. Also, it has been found that smokers show lower active glycoprotein Ilb/llla expression compared to nonsmokers [12] that potentiates antiplatelet effect. This may be because of the way that platelet reactivity is being evaluated, where the same number of platelet is used to assess platelet inhibition post any type of intervention to be studied.

The finding of no effect of smoking on pharmacokinetics of clopidogrel is of importance as there is strong evidence that indicates a publication bias against negative findings. Assessment of the number of meeting-abstracts that turn onto full papers revealed that a trial showing a benefit of a drug or device has much greater chance of full publication than does a trial showing no benefit [32].

Of interest is the observed differences between smokers and non-smokers in relation to the level of LDL-cholesterol [33,34], GGT [35] and blood urea nitrogen [36].

Reasons behind these differences are not yet well known. Liver enzyme GGT is higher in smokers because cigarette smoking might induce liver injury by enhancing lipid membrane peroxidation and cause cell destruction that is responsible for the liver enzyme leakage to systemic circulation.

Lipid profile seems to be altered among smokers. Lower HDL level and higher LDL level have been noticed among different ethnic groups. The high LDL level among smokers has been linked to increase lipolysis by stimulation of the adrenal system, increasing catecholamine, and hence increasing the TG, free fatty acids and VLDLcholesterol. Nicotine is one of the main constituents of cigarette that has been found to cause increase in triglyceride, cholesterol and VLDL-cholesterol levels and to decrease HDLCholesterol levels. Also it has been found that nicotine increases the circulatory pool of atherogenic LDL-cholesterol via accelerated transfer of lipids from HDL-cholesterol and impaired clearance of LDL-cholesterol from plasma compartment therefore it increases the deposition of LDL-cholesterol.

Many factors could cause a lower level of serum urea compared to non-smokers, of these; smokers had been found to consume less quantity of dietary proteins compared to nonsmokers which may cause lower amount of urea level and lower level to be excreted [36].

\section{Limitations of the study}

The findings of this paper are limited by the small sample size included in the study. The needed sample size was calculated based on previously published pharmacokinetics parameters of 600 $\mathrm{mg}$ clopidogrel [14]. The difference to be detected between smokers and non-smokers was set at $33 \%$ as a clinically significant difference was hypothesized to equal or to be larger than intrinsic variability reported in the pharmacokinetics behavior of clopidogrel $[14,17,20,22]$. The AUC calculated for the 34 patients was lower than anticipated in the sample size calculation, and our study would not have been able to detect the specified difference in AUC between smokers and non-smokers.

The recruited patients suffered from multiple medical conditions and were on a large list of medications with the potential to confound the finding of current study. It is practically difficult to select patient who are not on medications that may interfere with pharmacokinetics of clopidogrel as all of them are elders with multiple diseases. Still, the study population is reflection of actual medical practice.

The study was limited to male gender, further research has to include women as gender differences may have a more pronounced effect on cytochrome (CYP) 3A4 [26].

Moreover, the sampling time in the current study was short as it was limited to $8 \mathrm{~h}$ post treatment. More time is needed (24-48 $h$ ) to have a better estimation of terminal half-life. Unfortunately, this is not feasible in real life situation where real patients are being recruited and most of them are discharged after less than $24 \mathrm{~h}$ post stenting. It should be noted that several other studies terminated sampling by $8 \mathrm{~h}$ or even less $[14,37]$. 
Additionally, the study assumed that changes in clopidogrel carboxylate mirror changes in the active thiol metabolite. Clearly, more research is needed to clarify the effect of smoking on the pharmacokinetics of the active thiol metabolite of clopidogrel.

\section{CONCLUSION}

Findings from this study reveal that smoking affects at least one clopidogrel carboxylate pharmacokinetic parameter in smokers, but it may not be a significant determinant of the pharmacokinetics of $600 \mathrm{mg}$ clopidogrel in patients undergoing $\mathrm{PCl}$.

\section{ACKNOWLEDGEMENT}

The authors would like to thank all patients who participated in the study and all the medical and nursing staff at the catheterization laboratory of Jordan University Hospital. This study was supported in part by an unconditional grant from the Deanship of Scientific Research (University of Jordan).

\section{REFERENCES}

1. Jarvis B, Simpson K. Clopidogrel: a review of its use in the prevention of atherothrombosis. Drugs 2000; 60(2): 347-377.

2. Patrono $C$, Bachmann F, Baigent $C$, Bode $C$, De Caterina $R$, Charbonnier B, Fitzgerald D, Hirsh J, Husted S, Kvasnicka $J$ et al. The task force on the use of antiplatelet agents in patients with atherosclerotic cardiovascular disease of the European Society of Cardiology. Eur Heart J 2004; 25: 166-181.

3. Savi P, Herbert JM. Clopidogrel and ticlopidine: P2Y12 adenosine diphosphate-receptor antagonists for the prevention of atherothrombosis. Semin Thromb Hemost 2005; 31(2): 174-183.

4. Snoep JD, Hovens MM, Eikenboom JC, van der Bom JG, Jukema JW, Huisman MV. Clopidogrel nonresponsiveness in patients undergoing percutaneous coronary intervention with stenting: a systematic review and meta-analysis. Am Heart $J$ 2007; 154(2): 221-231.

5. Ellis SG, Colombo A, Grube E, Popma J, Koglin J, Dawkins KD, Stone GW. Incidence, timing, and correlates of stent thrombosis with the polymeric paclitaxel drug-eluting stent: a TAXUS II, IV, V, and VI meta-analysis of 3,445 patients followed for up to 3 years. J Am Coll Cardiol 2007; 49(10): 1043-1051.

6. Wilhelmsson $C$, Vedin JA, Elmfeldt $D$, Tibblin $G$, Wilhelmsen L. Smoking and myocardial infarction. Lancet 1975; i: 415-420.
7. O'Gara PT, Kushner FG, Ascheim DD, Casey DE, Jr., Chung MK, de Lemos JA, Ettinger SM, Fang JC, Fesmire FM, Franklin BA et al. 2013 ACCF/AHA guideline for the management of ST-elevation myocardial infarction: executive summary: a report of the American College of Cardiology Foundation/American Heart Association Task Force on Practice Guidelines. Circulation 2013; 127(4): 529555.

8. Gurbel PA, Bliden KP, Logan DK, Kereiakes DJ, Lasseter KC, White A, Angiolillo DJ, Nolin TD, Maa JF, Bailey $W L$ et al. The influence of smoking status on the pharmacokinetics and pharmacodynamics of clopidogrel and prasugrel: the PARADOX study. J Am Coll Cardiol 2013; 62(6): 505-512.

9. Ferreiro JL, Bhatt $D L$, Ueno M, Bauer D, Angiolillo DJ. Impact of Smoking on Long-Term Outcomes in Patients with Atherosclerotic Vascular Disease Treated with Aspirin or Clopidogrel: Insights from the Clopidogrel versus Aspirin in Patients at Risk of Ischemic Events (CAPRIE) Trial. J Am Coll Cardiol 2014; 63(8):769-777.

10. Gagne JJ, Bykov K, Choudhry NK, Toomey TJ, Connolly $J G$,Avorn J. Effect of smoking on comparative efficacy of antiplatelet agents: systematic review, meta-analysis, and indirect comparison. BMJ 2013; 347: $f 5307$.

11. Jeong YH, Cho JH, Kang MK, Koh JS, Kim IS, Park Y, Hwang SJ, Kwak CH, Hwang JY. Smoking at least 10 cigarettes per day increases platelet inhibition by clopidogrel in patients with ST-segment-elevation myocardial infarction. Thromb Res 2010; 126(4): e334-338.

12. Bliden KP, Dichiara J, Lawal L, Singla A, Antonino MJ, Baker BA, Bailey WL, Tantry US, Gurbel PA. The association of cigarette smoking with enhanced platelet inhibition by clopidogrel. J Am Coll Cardiol 2008; 52(7): 531-533.

13. Mohiuddin SM, Mooss AN, Hunter CB, Grollmes $T L$, Cloutier DA, Hilleman DE. Intensive smoking cessation intervention reduces mortality in high-risk smokers with cardiovascular disease. Chest 2007; 131(2): 446-452.

14. Taubert $D$, Kastrati $A$, Harlfinger S, Gorchakova O, Lazar $A$, von Beckerath $N$, Schomig $A$, Schomig $E$. Pharmacokinetics of clopidogrel after administration of a high loading dose. Thromb Haemost 2004; 92(2): 311-316.

15. Yousef A.M, Diab O, Arafat T, Khribash A, El-Saleh A, AlHroub H. Pharmacokinetics of $600 \mathrm{mg}$ loading dose of clopidogrel in patients undergoing percutaneous coronary intervention APJJ 2013; 7(11): 574-584.

16. Smith SC, Jr., Feldman TE, Hirshfeld JW, Jr., Jacobs AK, Kern MJ, King SB, 3rd, Morrison DA, O'Neil WW, Schaff HV, Whitlow PL et al. ACC/AHA/SCAI 2005 guideline update for percutaneous coronary intervention: a report of the American College of Cardiology/American Heart Association Task Force

Trop J Pharm Res, April 2015; 14(4): 699 
on Practice Guidelines (ACC/AHA/SCAI Writing Committee to Update 2001 Guidelines for Percutaneous Coronary Intervention). Circulation 2006; 113(7): e166-286.

17. Caplain H, Donat F, Gaud C, Necciari J. Pharmacokinetics of clopidogrel. Semin Thromb Hemost 1999; 25 Suppl 2: 25-28.

18. Clarke TA, Waskell LA. The metabolism of clopidogrel is catalyzed by human cytochrome P450 $3 A$ and is inhibited by atorvastatin. Drug Metab Dispos 2003; 31(1): 53-59.

19. Nirogi RV, Kandikere VN, Shukla M, Mudigonda K, Maurya S, Boosi R. Quantification of clopidogrel in human plasma by sensitive liquid chromatography/tandem mass spectrometry. Rapid Commun Mass Spectrom 2006; 20(11): 1695-1700.

20. Souri E, Jalalizadeh $H$, Kebriaee-Zadeh A, Shekarchi M, Dalvandi A. Validated HPLC method for determination of carboxylic acid metabolite of clopidogrel in human plasma and its application to a pharmacokinetic study. Biomed Chromatogr 2006; 20(12): 1309-1314.

21. Berger JS, Bhatt DL, Steinhubl SR, Shao M, Steg PG, Montalescot G, Hacke W, Fox KA, Lincoff AM, Topol $E J$ et al. Smoking, clopidogrel, and mortality in patients with established cardiovascular disease. Circulation 2009; 120(23): 2337-2344.

22. Yousef AM, Arafat T, Bulatova NR, Al-Zumyli R. Smoking behaviour modulates pharmacokinetics of orally administered clopidogrel. J Clin Pharm Ther 2008; 33(4): 439-449.

23. Whitfield PF, Hobsley M. Comparison of maximal gastric secretion in smokers and non-smokers with and without duodenal ulcer. Gut 1987; 28(5): 557-560.

24. Iwao $T$, Toyonaga A, Ikegami $M$, Oho $K$, Sumino $M$, Sakaki M, Shigemori H, Harada H, Sasaki E, Tanikawa K. Gastric mucosal blood flow after smoking in healthy human beings assessed by laser Doppler flowmetry. Gastrointest Endosc 1993; 39(3): 400-403.

25. Jeurissen SM, Punt A, Boersma MG, Bogaards JJ, Fiamegos YC, Schilter B, van Bladeren PJ, Cnubben NH, Rietjens IM. Human cytochrome p450 enzyme specificity for the bioactivation of estragole and related alkenylbenzenes. Chem Res Toxicol 2007; 20(5): 798-806.

26. Oztekin S, Mavioglu O, Elar Z, Guven H, Kalkan S, Gurpinar $T$. The effects of gender and menopause on serum lidocaine levels in smokers. Eur J Drug Metab Pharmacokinet 2005; 30 (4): 231-234.

27. Miyoshi M, Mizuno M, Ishiki K, Nagahara $Y$, Maga $T$, Torigoe T, Nasu J, Okada H, Yokota K, Oguma $K$ et al. A randomized open trial for comparison of proton pump inhibitors, omeprazole versus rabeprazole, in dual therapy for Helicobacter pylori infection in relation to CYP2C19 genetic polymorphism. J Gastroenterol Hepatol 2001; 16(7): 723-728.

28. Raunio H, Hakkola J, Pelkonen O. Regulation of CYP3A genes in the human respiratory tract. Chem Biol Interact 2005; 151(2): 53-62.

29. Hukkanen J, Vaisanen T, Lassila A, Piipari R, Anttila S, Pelkonen O, Raunio H, Hakkola J. Regulation of CYP3A5 by glucocorticoids and cigarette smoke in human lung-derived cells. J Pharmacol Exp Ther 2003; 304(2): 745-752.

30. Walle T, Walle UK, Cowart TD, Conradi EC, Gaffney TE. Selective induction of propranolol metabolism by smoking: additional effects on renal clearance of metabolites. J Pharmacol Exp Ther 1987; 241 (3): 928-933.

31. Smoking and tobacco use; Health Effects of Cigarette Smoking, in Centers for Disease Control and Prevention. 2011.

32. Johnson RT, Dickersin K. Publication bias against negative results from clinical trials: three of the seven deadly sins. Nat Clin Pract Neurol 2007; 3(11): 590591.

33. Arslan E, Yakar T, Yavasoglu I. [The effect of smoking on mean platelet volume and lipid profile in young male subjects]. Anadolu Kardiyol Derg 2008; 8(6): 422425.

34. Gossett LK, Johnson HM, Piper ME, Fiore MC, Baker TB, Stein JH. Smoking intensity and lipoprotein abnormalities in active smokers. J Clin Lipidol 2009; 3 (6): $372-378$.

35. Wannamethee SG, Shaper AG. Cigarette smoking and serum liver enzymes: the role of alcohol and inflammation. Ann Clin Biochem 2010; 47(4): 321 326.

36. Rodger RS, Laker MF, Fletcher K, White TF, Heaton A, Ward MK, Kerr DN. Factors influencing normal reference intervals for creatinine, urea, and electrolytes in plasma, as measured with a Beckman Astra 8 Analyzer. Clin Chem 1985; 31(2): 292-295.

37. Zhang W, Han Y, Lim SL, Lim LY. Dietary regulation of Pgp function and expression. Expert Opin Drug Metab Toxicol 2009; 5(7): 789-801. 